\title{
DOI: 10.7596/taksad.v5i1.504
}

\section{1-1918 Yılları Arasında Türk Yurdu Dergisine Konu Olan Bazı Tartışma ve Polemikler}

\author{
Ümmet ERKAN ${ }^{1}$
}

\section{Öz}

Türk Yurdu Dergisi 1911 yılında yayın hayatına başlamış, Türk milliyetçiliğinin en uzun soluklu yayın organıdır. Rusya Türklerinin öncülük ettiği dergide Türklüğün her alanda yükselmesi amaçlanmıştır. Bu makalede Türk Yurdu dergisinin 1911-1918 yılları arasındaki sayılarından yola çıkılarak dergideki bazı kalem tartışmaları, mektuplar ve onlara verilen cevaplar incelenmiştir. $\mathrm{Bu}$ kalem tartışmalarında Türkçenin sadeleştirilmesinden ne anlaşılması gerektiği ve sınırları, eğitimde ideal eksikliği, eğitim dilinin Türkçe olması ve azınlık okullarının Osmanlı sosyal bünyesine verdiği zararlar, Tanzimatçı reform programının başarılı olup olmadığı ve nedenleri, milli kimliğin dini aidiyete zarar verip vermeyeceği konuları ele alınmıştır. Türk Yurdu dergisi yazarları ile dönemin diğer önemli entelektüellerinin çeşitli gazete ve dergilerde dâhil olduğu bu kalem tartışmaları zengin bir muhteva kazanmıştır. Bu tartışmalar dönemin entelektüel fikir hareketleri ve siyasi akımlar hakkında önemli bilgiler içermektedir. Bu araştırma, yapılan tartışma ve polemiklerin hangi konular etrafında yoğunlaştığını ve Türk Yurdu dergisinin bu tartışma ve polemiklerde ne tür bir yöntem izlediğini ortaya koymaktadır.

Anahtar Kelimeler: Türk Yurdu Dergisi, Milliyetçilik, Türk Milliyetçiliği, Tanzimat, Osmanlı'nın son dönemi.

\footnotetext{
${ }^{1}$ Dr. Ümmet Erkan. ummet_erkan@hotmail.com
} 


\title{
Some Polemics and Discussions which were Subjected In Turk Yurdu Magazine Between 1911-1918
}

\begin{abstract}
Started to press in 1911, The Turk Yurdu Magazine which is the longest press in Turkish Nationalism, leaded by the Turks in Russia whose aims were the Turkish Nation's going up in all areas. This article examines some polemics, letters and replies for these letters took place in the issues between the years 1911/1918. In this polemics, the topics of what should be understood from the simplification of Turkish and its boundaries, the lack of idealism in education, education with Turkish language, the damages of minority schools on the social life of Ottoman people, the success of the programs of Tanzimat, the effects of national ID on religious ID and the like were discussed. These polemics which the authors of Turk Yurdu and the other intellectuals who took place in the discussion from different newspapers and magazines got a very rich content. This article focuses on the topics which the debates revolves around and and the intellectual discussions about them.
\end{abstract}

Keywords: The Turk Yurdu Magazine, Nationalism, Turkish nationalism, Tanzimat, Late Ottoman era.

\section{Giriş}

Türk milliyetçiliğinin en uzun soluklu dergisi olan Türk Yurdu Dergisi, Türk Yurdu Cemiyeti’nin yayın organı olarak 17 Teşrinisani 1327 (30 Kasım 1911)'de yayın hayatına başlamıştır. Türk Yurdu Cemiyeti Mehmet Emin, Ahmet Hikmet, Hüseyinzâde Ali, Akil Muhtar, Yusuf Akçura tarafından kurulmuştur (Tunaya:1998, 415). Türk Yurdu Cemiyeti'nin kuruluşundan birkaç ay sonra Mehmet Emin, cemiyet adına bir dergi çıkarmayı düşünmüş fakat kendisinin 1911 Ağustos ayında Erzurum Valiliği'ne atanması üzerine bu görevi Yusuf Akçura üstlenmiştir. Türk Yurdu Cemiyeti’nin ömrü uzun olmamış, cemiyet üyeleri 12 Mart 1328 (25 Mart 1912) tarihinde kurulan Türk Ocağı'na katılmıştır. Türk Yurdu Dergisi 30 Ağustos 1917'den sonra Türk Ocağı'nın resmi yayın organı olmuştur (Suphi:1918, 225). 
II. Meşrutiyet (1909) sonrasında yaşanan olağanüstü gelişmeler, Türk milliyetçiliğinin bir seçenek olarak güçlenmesini sağlamıştır. 1911 Trablusgarp Savaşı, 1912-13 Balkan Savaşları ve 1914-1918 Birinci Dünya Savaşı büyük İmparatorluk sınırlarının çözülmesine yol açmıştır. Özellikle Balkan Savaşları Türklük bilinci üzerinde büyük bir etki uyandırmıştır. Balkanlardan göçe zorlanan, baskı ve zulüm gören milyonlarca Türk Anadolu'ya sığınmıştır. $\mathrm{Bu}$ durum hem Anadolu nüfusunu homojenleştirmiş ve hem de Türk ve Müslüman olduğu için zulme uğrayan bu insanlarda Türklük bilincini güçlendirmiştir.

1908 sonrasında göreli bir özgürlük ortamı içerisinde, amacı Türk milliyetçiliğini tahkim etmek olan - öncülügüüü Rusya Türklerinin yaptığı - bazı vakıf, dernek ve cemiyetler kurulmuştur. Bunlardan birisi olan Türk Derneği 1908 yılında kurulmuştur. Dernek, Türk Derneği Dergisi adı altında bir de dergi çıkarmıştır. Derneğin amacı; "Cemiyetin maksadı Türk diye anılan bütün kavimlerin mazi ve haldeki asar, ef'al, ahvalini ve muhitini öğrenmeye ve öğretmeye çalışmak...” (Anonim: 1911a, 165) Türk milletine dair yazılan ilmi eserleri incelemektir. Şubelerden bulundukları yöre ve bölgelerde kullanılan Türkçe kelimeleri, Türkçe deyişleri, atasözleri, masal, ninniler, türkü ve şarkıları kaydetmeleri istenmiştir. Yaşadıkları yerlerde daha önce egemen olmuş Türk devletleri ve orada yerleşik halkın kökeni ile ilgili bilgiler istenmiştir (Anonim: 1911 b, 199-200).

1912 yılında Tıbbiye öğrencilerinin öncülük ettiği Türk Ocă̆g'nın kurucuları Mehmet Emin, Ahmet Ağaoğlu, Dr. Fuat Sabit'tir. 18 Mayıs 1913'te Ocak başkanlığına seçilen, etkili hitabeti ve saygın kişiliği ile tanınan Hamdullah Suphi, Ocağın her kesimden insanın sempatisini kazanmasını sağlamıştır (Akçura:2008, 175-177). Türk Ocağı'nın kuruluş amacı beyannamesinde şöyle ifade edilmiştir: "Cemiyetin maksadı, akvam-1 İslamiyenin bir rüknü mühimi olan Türklerin millî terbiye ve ilmî, içtimai, iktisadi seviyelerinin yükseltilmesi ve yüceltilmesiyle Türk 1 rk ve dilinin mükemmelleşmesine çalışmaktır." Cemiyet bu amacını gerçekleştirmek için kulüpler kuracak, dersler, konferanslar verecek, kitap ve risaleler basacak, okullar açacaktır. Cemiyet, iktisadi hayatın geliştirilmesine de çalışacaktır. Dördüncü maddede Ocağın amaçlarını gerçekleştirirken sadece milli amaçları gözeteceği ve siyasetten uzak duracağı belirtilmiştir (Üstel:1997, 100-104). 
1908 sonrasında siyasal bir alternatif olarak güçlenen Türk milliyetçiliğinin öncülügünü Rusya Türkleri üstlenmiştir. Rusya Türkleri üzerinde dönemin en etkin ismi Kırımlı İsmail Gaspıralı'dır. Gaspıralı, Rusya'nın Türkistan'ı istila hareketinin başarıya ulaşması ile birlikte Rus işgaline karşı köklü reformlar yapılmadan başarı sağlanamayacağını anlamıştır. 1883 yılında Kırım'da Tercüman gazetesini çıkarmaya başlamıştır. Tercüman gazetesi Rusya Türkleri için yol gösterici olmuştur. Gaspıralı’nın bu gazetede takip ettiği başlıca amaçlar; Batılı metotlarla eğitim yapan okullar açmak, Rusya Türklerini birleştirmek, Osmanlı Türkçesini bütün Türkler için ortak bir dil haline getirmektir (Devlet:2011, 108-109). Gaspıralı'nın izinden giden Yusuf Akçura, Ahmet Ağaoğlu, Sadri Maksudi gibi isimler Türkçü cemiyet, dernek, gazete ve dergilerde etkili isimler olmuştur.

Türk Yurdu Dergisi yazarları incelendiğinde Rusya Türkleri’ne ilave olarak dönemin etkili kalemlerinin dergiye katkıda bulunduğu görülmektedir. Sosyolog Ziya Gökalp, şair ve yazar Mehmet Emin, Ahmet Hikmet, Abdülhak Hamit, İzzet Ulvi, Ali Canip, Ömer Seyfettin, Türkolog Necim Asım, Mehmet Fuat, iktisatçı Parvus Efendi, Eğitimci Nafi Atuf, Mimar Kemalettin, sosyalist Ethem Nejat gibi. Türk Yurdu Dergisi alanlarında uzman yazarların buluştuğu bir düşünce okulu olmuştur. Derginin yayın ilkeleri incelendiğinde "Türklügün her alanda yükselmesine", Türkler arasında ortak bir ideal geliştirmeye, Türklerin tanışmasına ve kaynaşmasına çalışacağı belirtilmiştir (Akçura:2008, 168). Dergide gündelik siyasetin dışında kalarak Türklerin her tür sorununun tartışılacağı belirtilmiştir.

Türk Yurdu Dergisi 1911-1918 yılları arasında 14 cilt ve 161 sayı çıkmıştır. Derginin son sayısı 15 Ağustos 1918 yılında çıkmıştır. Mondros Mütarekesi (30 Ekim 1918) sonrasında dergi yazarlarından bazılarının (Ahmet Ağaoğlu, Ziya Gökalp vb.) tutuklanması, İstanbul'da özelikle Türk Ocağı üzerindeki baskılar - dernek binasının sürekli baskına uğraması - derginin çıkmasını olanaksız hale getirmiştir. 1924 yılında yeniden yayın hayatına başlayacak olan dergi 1931 yılında Türk Ocağı'nın kendini feshetmesi ile kapanmıştır. Sonrasında ise çeşitli fasılalarla çıkmaya devam etmiş, bugün 100 yıllık bir dergidir. Türkiye'de özellikle dergi yayıncılığı içerisinde 100 yılı aşmış, köklü bir maziye dayanan, ülkenin yaşamış olduğu çeşitli sosyolojik kırılmalara şahitlik etmiş dergi sayısı çok fazla değildir. Bu dergilerde yaşanan çeşitli fikir tartışmaları, kalem kavgaları (polemikler) dönemin siyasi, toplumsal, kültürel koşullarını analiz etmede 
önemli katkılar sağlayacaktır. Bu makalede derginin özellikle 1911-1918 yılları arasındaki sayıları seçildi. Bu dönemin seçilmesinde farklı fikir akımlarının (Osmanlıcılık, İslamcılık, Türkçülük, Batıcılık, Sosyalizm vb.) Osmanlı Devleti’nin içine düştüğü “hastalık”tan kurtarılması için çeşitli çözüm reçeteleri sunması ve bunlar arasında var olan çok güçlü fikir tartışmalarının dönemin entelektüel canlılığını yansıtmasından dolayıdır. Bu dönemde her fikir akımı kendi görüşlerini yaymaya ve etkili bir kamuoyu oluşturmaya çalışmıştır. Aydınlar arasındaki bu kalem kavgalarının bugün de hala devam eden çeşitli tartışmalarla ilgili olması ve bu tartışmaların bugün de canlılığını korumaya devam etmesi bu makalenin yazılmasında etkili olan nedenlerin başında gelmektedir.

$\mathrm{Bu}$ makalede arşiv ve kaynak taraması yapılmıştır. Türk Yurdu Dergisi dışında dönemin yayın organlarından Jön Türk, Tanin, Tasvir-i Efkâr, Hak, Genç Kalemler, Türk Derneği, Sebilürreşat gibi gazete ve dergilerin ilgili sayıları analiz edilmiştir. Bazen doğrudan alıntılar yapılmış, bugün anlaşılmasının güç olacağı düşünülen bazı kavramlar köşeli parantez içinde verilmiştir.

Makale dört ayrı kalem kavgasını içermektedir. İlk bölümde Türk dilinin sadeleştirilmesi üzerinden başlayan dilde sadeleşmenin hangi düzeyde ve nasıl yapılması gerektiği tartışması ele alınacaktır. İkinci bölümde eğitimde ideal eksikliği, yabancı okullarda misyonerlik yapılması ve eğitimin milli bilinci güçlendirmedeki yetersizliği kalem kavgasının temel konusudur. Üçüncü bölümde Tanzimatçılık üzerine başlayan kalem kavgasında Yunus Nadi, Mehmet Fuat, Yusuf Akçura gibi isimlerin görüşleri analiz edilecektir. Son bölümde ise kalem kavgasının konusu milli kimlik ile dini aidiyet arasında bir karşıtlığın olup olmadığı ile ilgilidir.

\section{Dil ve Edebiyatla İlgili Kalem Kavgaları ve Mektuplara Verilen Cevaplar}

Türk Yurdu Dergisi, yukarıda da belirttiğimiz gibi Türklerde milli bilinci yükseltmeye çalışan, Türkler arasında ortak bir ideal geliştirmeyi amaçlayan bir dergidir. Türkler arasında bir fikir, amaç ve eylem birliği geliştirebilmek için herkesin anlayabileceği bir Türkçenin geliştirilmesi gereklidir. Bunun bir boyutu Türk dünyası arasındaki dil farklılıklarının (şive ve lehçe farklılıklarının) azaltılması (Gaspıralı'nın öncülük ettiği Osmanlı Türkçesinin bütün Türkler için ortak dil olarak kabul edilmesi) diğer boyutu ise Türkçenin sadeleştirilmesidir. Milli birliğin en önemli unsuru olan dil birliği ancak herkesin anlayabileceği ortak bir dil etrafında gerçekleşebilir. Bu yüzden milliyetçilerin ilk ele aldıkları konuların başında daima halkın dili ile aydınların dili 
arasındaki farkın azaltılması olmuştur. Gazetelerin bu alanda önemli hizmetler gördüğünü unutmamak gerekir. Türk Yurdu Dergisinin de amaçlarından birisi "yalın ve sade bir Türkçe" kullanmaktır. "Çetin mevzuları bile kolay ifade olunmaya çalışılacaktır." (Akçura:2008, 168). Halkın konuştuğu Türkçenin en güzel Türkçe olduğu vurgulanmıştır (T.Y.:1911, 56).

Türk Yurdu Dergisi'nde ele alacağımız kalem kavgasının konusu Türkçenin sadeleştirilmesi gerekli olup olmadığı, eğer gerekli ise bunun hangi ölçüde olacağı ile ilgilidir. Esasen bu tartışma daha önce Türk Derneği dergisi ve Genç Kalemler'de de devam eden tartışmaların bir devamıdır. Türk Derneği dergisinde Ahmet Hikmet, İsmail Hakkı, Necip Asım gibi isimler Türkçenin halkın anlayabileceği bir biçime kavuşturulması gerekliliğini savunmuştur. Örneğin Ahmet Hikmet şunları dile getirmiştir:

"Artık meşrutiyet çağındayız. Müsavat [eşitlik] diye bağırıyoruz. Acaba şimdiye kadar hangi bir ceride [gazete] muharriri [yazarı] kadınların, işçilerin, askeri neferlerin, esnafın, köylülerin, çiftçilerin, yani ahalimizden pek çoğunun anlayacağı yolda konuştuğumuz gibi açık ibarelerle makaleler yazarak bize hürriyetin ululuğunu, meşrutiyetin değerini, vatan sevgisini anlattı." (Hikmet:1911, 47).

Benzer tartışmalar Selanik'te çıkan Genç Kalemler dergisinde de yaşanmıştır. Kazım Nami, Ali Canip gibi isimler Türkçenin sadeleştirilmesi konusunu ele almıştır. Kazım Nami’ye göre Türkçeyi halkın konuştuğu dile uygun hale getirmek gereklidir. "Lisanı böyle sadeleştirebilirsek, öyle zannederiz ki Türkçeliği daha aşikâr bir surette meydana çıkar. Ona üç lisandan mürekkep bir acibe, bir "Osmanlıca" diyenleri cesareti de kırılır. Dilimiz, Türkçedir. Bütün Türk lehçeleriyle mukayese ederken buna Osmanlı Türkçesi deriz...” (Nami:1911, 132).

Yukarıda dile getirilen sade ve yalın bir Türkçe anlayışının devrin bazı yazarları tarafından hoş görülmediği anlaşılmaktadır. Bunu gösteren kanıtlardan birisi Türk Yurdu Dergisinde yaşanmıştır. Dergiye bir mektup yazan Mithat Cemal, önce derginin Türk düşünce hayatına getirmiş olduğu canlılığı belirtmiş sonra ise asıl meramını dile getirmiştir. Mithat Cemal'in merak ettiği bu derginin eski edebiyatı diriltmek mi? Eski geleneği izleyerek devam etmek mi? Yoksa yeni bir edebiyat taraftarı mı olduğudur. Kendisinin eski edebiyatımızı yeniden diriltmek taraftarı olduğunu belirtmiştir (Cemal:1913, 84-85). Yusuf Akçura, Mithat Cemal'e cevap verdiği makalesinde kendi 
görüşlerini dile getirmiştir. Akçura, dilin doğal bir seyir izlediğini, tekâmül ettiğini ve dildeki sadeleşme eğiliminin edebiyatı herkesin izleyip anlayabileceği ve zevk alabileceği bir hale getirdiğini söyler.

"Şimdi biz açık, sade yazılarla bütün Türkleri, hatta ümmîlerini bile yaşatmak istiyoruz; siz bizi eslâfı [öncekileri] öldürmek arzusuyla itham ediyorsunuz! Buna karşı biz de size: "Ölüleri yaşatmak isterken, dirileri öldürüyorsunuz. Bırakın şu millet biraz kendine hitap olunduğunu işitsin, varlığını, benliğini anlasın; yaşadığını duysun. Lalanız Ahmet Ağa da, dadınız Dilber Kalfa da bizim gibi insan, bizim gibi Türkler. Niçin tatlı şiirlerinizden onlar da lezzet almasınlar, müstefit olmasınlar?" dersek Türklüğün temelini, ekseriyetini teşkil eden o kimsesiz, mütevazı ruhlar, mutlaka bize hak verirler..." (Akçura:1912a, 149).

Akçura, verdiği yanıtta dilde ölçünün halkın konuştuğu dil olduğunu, aydınlarla halk arasındaki dilsel uçurumu, iletişim eksikliğini gidermeye çalıştıklarını belirtmiştir. Dergiye gönderilen ikinci mektup Celal Nuri imzası taşımaktadır. Celal Nuri Türk Yurdu Dergisinin çıkmasını çok önemli bulduğunu ve bir boşluğu doldurduğunu belirttikten sonra dergide kullanılan dili eleştirir. Bu dili "suni” ve "gayrı tabii” bulduğunu belirtir:

"Osmanll, Rus, İran, Çin, Bulgar, ilh, gibi devletlerin tâbiiyeti altında bulunan ve adedi behemehâl elli milyona baliğ olan Türkler için yurdunuz mühim bir merkezdir. Türk âlemi böyle bir merkeze muhtaç idi, Siz bu ihtiyacı defe çalışıyorsunuz. Yalnız, biraz dilinizi, üslubunuzu muahezeye [eleştirmeye], müsaade buyurur musunuz? Buyurur iseniz mektubumu muhterem mecmuanıda dercedersiniz [eklersiniz]. Muharrirlerinizin [yazarlarının] ihtiyar ettiği [seçtiği] lisanı biraz sunî, biraz gayr-1 tabii buluyorum. Yeni ve gayr-1 menus [alışılmadık] kelimeler, yeni ve gayr-1 menus terkipler, yeni ve gayr-1 menus fikirler Türk Yurdu'nda maatteessüf pek mebzul [bol]! Muharrirleriniz bilmelidirler ki bir lisan ihtira [türetme] ve icat edilmez... Lisan terakki eder, tekâmül eder fakat tebeddül ve tagayyür etmez [değişmez]. Lisanı tebdil [değiştirmek] etmek Esperanto gibi bir ucube-i beyan ihdas etmektir... Hülâsa-i kelâm lisanı değiştirmeğe çalışmak onu ihlâl etmek, berbat etmek demektir. Maalesef okuduğum bazı makalelerde ve hususiyle şiirlerde bilmediğim ve görmediğim bir lisanı, gayr-1 mevcut bir lisanı görüyorum. O yeni ve gayr-1 menus kelime ve terkipler ne Osmanlı, Rus 
Türkçelerinde, ne Azerbaycan ve Türkistan Türkçelerinde mevcuttur, Terakki edelim, fakat bozmakla değil; teceddüt edelim, fakat mahiyetimizden çıkmakla değil. Lisan muhafazakârlıkla terakki eder. Lisanda fazla liberalizm -emin olunuz- dekadans, tedenni [gerileme], tefessüh [bozulma] demektir.” (Nuri:1912, 147-48).

Celal Nuri açıkça bu sade Türkçenin yapmacık bir dil olduğunu, dil üzerinde yapılan bu tür düzeltme denemelerinin dilin doğal gelişimini bozacağını savunmuştur. Yusuf Akçura dergide bu mektuba verdiği yanıtta yeni bir dil yaratmak gibi bir niyetlerinin olmadığını, amaçlarının sadece dili daha anlaşılabilir bir hale getirmek olduğunu, dilde bir tasfiye taraftarı olmadıklarını belirtir.

“...Bendeniz de lisanların tekâmülüne ait ilmî müşâhedâtın [gözlemlerin] münkirlerinden [inkârcılarından] değilim. "Türk Yurdu" muharrirlerinden hiç birisinin lisanı değiştirmeye çalışmak arzusunda bulunduğunu da zannetmem, Hepimizin istediği ancak "lehçeyi tasfiye, tarz-1 beyanı sadeleştirmek, kudemâperestâna [eskiye bağlılık] ait kelime ve cümlelerden" imkân derecesinde kurtulmaktır. Eğer başka türlü zehapların doğmasına sebep oluyorsak, emin olunuz ki bu, esasen başka türlü düşünmekten değil, belki kabul ettiğiniz esası fiilen gereği gibi tatbike muvaffak olamamaktandır." (Nuri:1912, 148).

Türk Yurdu Dergisi'nde yeni dil taraftarı ve buna uygun eserler üreten öncü isim Mehmet Emin (Yurdakul)'dir. Dergide Mehmet Emin Bey'in bu şiir anlayışını destekleyen, Macar asıllı Türkolog A. Vambery (1832-1913) ömrünün son yıllarında Mehmet Emin'e yazdığı bir mektup yayınlanmıştır. Vambery bu mektubunda Mehmet Emin'in öncülük ettiği milli edebiyat akımından övgüyle söz etmiştir. "Ey sevgili tanırım (Dostum). Ve yurt muhabbetinde kaim Türk kardaşım... Bu gün mümkün olmayan şey inşallah yakında daire-i imkâna girecektir. Ve eğer zât-1 fazâyilmât-1 âliyeniz gibi birkaç vatan ve millet muhabbetinde gayret gösteren Osmanlı meydana çıkacak olursa, elbette tatlı lisanınız makam-1 ihtirama yetişip millet-i necîb-i Osmaniyân yeniden ihya olup benim o ân-1 şebabetimde [gençliğimde] arzu ettiğim meramımı fiiliyatta görmeğe müyesser olacağım efendim, azizim.” (A. Vambery: 1913, 70).

Özetle Türk Yurdu Dergisinde dille ilgili yaşanan kalem kavgaları dilde sadeleşmenin gerekli olup olmadığı ve bunun boyutları ile ilgili olmuştur. Türk milliyetçiliğinin en güçlü yayın organlarının başında gelen Türk Yurdu Dergisinin nasıl bir 
dil politikası izleyeceği merak edilmiş, dergiye gönderilen mektuplarda da buna yönelik izahat istenmiştir. Derginin yayın politikasının Osmanlıcayı büsbütün tasfiye etmek değil fakat halkın konuştuğu dili merkeze alarak iletişime açık, sade bir Türkçe taraftarı olduğu dile getirilmiştir.

\section{Eğitimle İlgili Kalem Kavgaları}

Türk Yurdu Dergisi İsmail Gaspıralı’nın Türkistan’da başarı ile uyguladığı eğitim reformundan sık sık övgüyle söz etmiş, Osmanlı Devleti’nde de eğitimin yeniden düzenlenmesi taraftarı olmuştur. Eğitimle ilgili analizler dergide çok yer almamış, bunun nedeni olarak da bu konuda yetişmiş uzman eksikliği dile getirilmiştir:

"Maksadımız millî bir terbiye gayesine müteveccih olmak üzere zamanımızda az çok takarrür eden talim ve terbiye usûllerine ve bu usûllere vâsıl olmak için geçirilen edvara bir ilm-i mücmel [kısa bir özet] husule getirecek surette makaleler neşretmekti. Karilerimiz [okuyucularımız] her sınıf ve sanata mensup kimselerden mürekkep olduğu cihetle terbiyevî makalelerimizin yalnız muallimlik ve mürebbîlik mesleğinde bulunanlara müfid [faydalı] olacak gibi mütehassısane [uzmanlık gerektiren] ve ağır yazılmayıp, herkesin anlayarak ve sıkılmayarak okuyacağı veçhile yazılması da gözettiğimiz şartlardandı." (Anonim:1916).

Türk Yurdu Dergisinde eğitimle ilgili olarak Nafi Atuf, İsmail Gaspıralı, Ispartalı Hakkı'nın analiz ve yorumları dergide yer almıştır. Bu yazılarda Osmanlı eğitim sisteminin temel sorunları dile getirilmiştir. Dergide sık sık dile getirilen temalardan birisi eğitimin bireylere ideal yüklemedeki yetersizlikleri olmuştur. Bu bölümde eğitimde ideal eksikliği, azınlık okullarındaki misyonerlik çalışmaları, eğitim dili ve eğitimin temel soruları konularında yaşanan kalem kavgaları ele alınacaktır.

Akçura "Emel ve İdeale" başlıklı yazısında Osmanlı eğitim sisteminde öğrencilere yeterince ideal yüklenmediğini savunmuş, bundan söz ederken de sözü azınlık okullarına getirmiştir. Azınlık okullarının Türk gençlerini kendi idealleri etrafında yetiştirmeye çalıştığını söylemiştir (Akçura:1912b, 268). Akçura'nın bu yazısı yine dergi yazarlarından Halide Edip Hanım'ı kızdırmıştır. Akçura'ya Tanin gazetesinde cevap vermiştir. Bu yazısında bütün azınlık okullarının aynı olmadığını, bütün azınlık okullarında misyonerlik

yapılmadığını savunmuştur (Edip:1912, 3). Kendisi Üsküdar Amerikan Koleji mezunu 
olan Halide Edip, buradaki göndermeden belli ki rahatsız olmuş ve yazıya cevap verme ihtiyacı hissetmiştir. Ona göre Üsküdar Amerikan Koleji on seneden beri misyonerlerin idaresinden çıkmıştır. Kendisinin bu okulların avukatlığını yapmaya çalışmadığını fakat bu okullar hakkında önyargılı olunmaması gerektiğini söylemiştir. Halide Edip yazısının devamında; "ben bütün kalbimle memlekette umumi mekteplerin laik olması taraftarıyım ve böyle olmadıkça o millet ve memleket hakikat ve ilim ve marifet de, medeniyette hiçbir vakit ileri gidemezler..." (Edip:1912, 3) diyerek laik eğitim taraftarı olduğunu ifade etmiştir.

Yusuf Akçura, Halide Edip'e verdiği yanıtta eski medreselerin çağını doldurmuş olmasına rağmen yine de genç nesillere bazı misyonlar yükleyebildiğini, yeni okullarda ise gençlerin büsbütün idealsiz, çıkarcı, menfaatçi yetiştiklerini söylemiştir (Akçura:1912c, 303). Kendisinin bütün yabancı okulları aynı biçimde görmediğini de belirterek Halide Edip'e hak verdiğini göstermiştir. "Ecnebi mekteplerinden çıkan kadın, erkek kim olursa olsun -bila istisna- gayesiz, hatta belki muzır bir insan olmaya mutlaka mahkûmdur" diye de hiç düşünmedim. Binaenaleyh müddeanızın [iddianızın] ikincisinde de fikren ihtilafımız yoktur (Akçura:1912c, 303). Kendisi Fransa'da siyaset bilimi okumuş Akçura'nın elbette Bat1 düşüncesine bir düşmanlığı yoktur. Onun buradaki temel düşüncesi bu okullardan yetişenlerin ülke meselelerine yeterince önem vermediğidir. Ama benzer durumun Osmanlı okullarında da olduğunu kendisi de ifade etmiştir.

Bu konuyla ilgili başlayan kalem kavgasına katılan diğer bir isim de dönemin Türk kadın hareketleri içerisinde önemli bir ismi olan Nezihe Muhlis (Muhittin)'tir. Nezihe Muhlis yazısında Akçura'nın yabancı okullarla ilgili görüşlerine katılmadığını söylemiştir. Kendisi de bir azınlık okulundan mezun olan Nezihe Muhlis şu görüşleri dile getirmiştir:

"Ecnebi mektepleri hakkındaki fikrinizi kabul etmiyorum. İnsan orada muhtelif kavmiyetleri görerek kendisinin, ne olduğunu düşünmeye, belki de kendisinin Türk olduğunu anlayıp hükmetmeye bir vesile bulur. Ecnebi mekteplerinde kendi milliyetleri pek muhterem tutulduğundan insanda hiss-i millî daha kuvvetli, daha çabuk doğar. Halide Edip Hanımefendi'nin fikirlerine müşterekim [aynı fikirdeyim].” (Muhlis:1912).

Nezihe Muhlis de benzer biçimde bu okullarda gençlerin kendi kimliklerinin farkına vardıklarını, bu yönüyle bu okulların milli düşüncenin gelişmesine yardım ettiğini söylemiştir. Burada gerek Halide Hanım gerekse Nezihe Hanım'ın belirttiği gibi bir tehlike 
söz konusu değil midir? 1911 yılında Hak gazetesinde çıkan yazısında Ahmet Ağaoğlu azınlık okullarının Osmanlı sosyal bünyesini nasıl bir ahtapot gibi sardığını anlatan bir makale yayınlar. Makalesinde şu görüşleri dile getirmiştir: "Osmanlı İmparatorluğu dâhilinde çalışan dini heyetlere Fransa hükümeti senede 1.200.000 Frank tahsisat vermekte idi. Rusya kendi himaye ettiği mekteplere bu miktara yakın tahsisat verdiği gibi İtalya da 100.000 frank tahsisat veriyordu... Memaliki Osmaniyede [Osmanlı Devletinde] sair milletlerin ve kavimlerin malik oldukları mekteplerin yekûnu 10 yüksek, 46 idadi, 1450 iptidaiyi mütecavizdir [aşkındır]." Agayef'e göre gerçek rakamlar bu istatistiklerin de üstündedir. Ona göre yabancıların elinde 10.000 okul ve en az bu okullarda yarım milyon öğrenci bulunmaktadır. Ona göre bu okullarda eğitim alanların yüzde altmışı Müslüman çocuklarıydı. Müslüman öğrencilerin dinlerini öğrenmelerine yönelik herhangi bir eğitim yoktu. Öğrenciler Müslüman da olsalar sabah ve akşam dini ayinlerde bulunmak zorundaydılar. Bu okullarda yavaş yavaş Müslüman çocuklar kendi milli bilinçlerini kaybediyorlard1 (Akt. Ergin:1940, 668).

Görüldüğü gibi durum ciddidir. Azınlık okulları sosyal bünyeyi sarmıştır. Bu okullarda yetişen çocuklar kendi dinleri, kültürleri ve milliyetlerine yabancı yetişiyordu. $\mathrm{Bu}$ nedenle dergide yaşanan kalem kavgasının sosyal bir gerçekliğe dayandığı görülmektedir. Dergide elbette eğitimle ilgili pek çok konu dile getirilmiştir. Bunları burada sıralamak bir makalenin boyutlarını aşacaktır. Bunlardan kısaca değineceğimiz diğer bir konu eğitim dilinin Türkçe olması ile ilgilidir. Yusuf Akçura eğitim dilinin Türkçe olması gerektiğini, yabancı dil olarak da Fransızca yerine Almanca öğretilmesinin daha uygun olacağını savunmuştur (Akçura:1915, 41). Bu tercihte şüphesiz dönemin Almanya'ya yakın olma politikasının da etkileri sezilmektedir. Eğitimin Türkçe yapılması gerektiğini destekleyen bir başka makalede de Mehmet Fuat; milli dil yerine başka bir dille yapılacak eğitim milli kültür, milli terbiye gibi temel amaçlara büyük bir darbe vuracağını, dilimizin ve kültürümüzün bağımsızlığına engel olacağını savunmuştur:

"Millî lisanın hâkimiyetini en çok ihlâl edecek şeylerden biri de, tedrisatı ana lisanıyla değil yabancı bir dille icra edilen zahiren [görünüşte] millî veya resmî mekteplerdir. Herhangi milletin lisanı olursa olsun, Türk mekteplerinde asıl tedrisatın yabana bir dille icra olunması ve millî lisanın yalnız ecnebi bir lisan şeklinde kalması öyle büyük bir felâkettir ki, millî hislerle çarpan yürekler için, bu, manevî vatan üzerinde yabancı bir bayrağın temevvücü kadar ye's-âlûd 
[ümitsiz], matemli bir manzara teşkil eder... Yarınki büyük Türk vahdet-i milliyesini [milli birliğini] ancak millî irfan ile ve millî irfanı ise yalnız millî lisan ve millî edebiyat sayesinde tesis edebileceğiz." (Fuat: 1914).

Özetle eğitimle ilgili kalem kavgalarında temel konular eğitimin gençlere ideal yükleyememesi, azınlık okullarının sosyal bünyede neden olduğu tahribat ve eğitimin Türkçe yapılmasının gerekliliği olmuştur.

\section{Tanzimatçılık Hakkında Kalem Kavgaları}

$\mathrm{Bu}$ bölümde inceleme konusu yapacağımız kalem kavgası Tanzimatçılığın başarılı olup olmadığı, başarılı olamamışsa bunun nedenleri hakkında olacaktır. Bu kalem kavgalarında ağırlıklı olarak Tanzimat bürokrasisinin reformları ele alış tarzları ve yöntemlerindeki eksiklikler eleştiri konusu yapılmıştır. Kalem kavgasının tarafları Yusuf Akçura, Yunus Nadi, Ahmet Ağaoğlu ve Mehmet Fuat'tır. Tanzimatçılık hakkında ilk değerlendirme Yunus Nadi'den gelmiştir. Nadi’ye göre Tanzimat düşüncesi her şeyi Batı'dan aktarmayı düşünmüş ve Doğu'yu ihmal etmiştir. "Milletin terakki ve tekâmülü için taklit yolu demek olan Tanzimat usulü hiç de kâfi değildir." (Nadi:1913). Nadi’ye göre Tanzimatçılar Batılı tarzda okullar açmış, fakat geleneksel eğitim kurumları olan medreseleri ihmal etmişlerdir. Nizamiye mahkemelerini kurmuş ve fakat eski yargılama biçimi de devam etmiştir. Eski ile yeni birlikte yaşatılmaya çalışılmış, fakat bu iki kurum birbiri aleyhine çalışmıştır. Milliyet bilinci kazandırmak konusunda ise Tanzimatçılar hiçbir adım atmamıştır.

"Milliyet meselesi ise Tanzimatçıların hiç hatır ve hayalinden geçmemiş idi. Binaenaleyh devr-i Tanzimat'tan itibaren terakki ve tekâmül nâmına atıldığı iddia olunan batevât, hep evham ve hayalâta [hayallere] istinad eylemiştir [dayanmıştır]. Bunun neticesi kendi mahsûsat-1 kavmiye ve milliyesine sahip bir millet hâlinde taazzuv [şekillenme] ve teşekkül edememekliğimiz suretinde tahakkuk etti. Fakat Tanzimatçılık gerçi iflâs etti; fakat bize de işte görülüyor ki pek pahalıya mal oldu." (Nadi:1913).

Ahmet Ağaoğlu bu tartışmaya Jön Türk gazetesindeki yazısıyla katılmıştır. Ağaoğlu'na göre Batılılaşmak ihtiyacı Osmanlı toplumsal bünyesine taklitçilik şeklinde girmiştir: 
"Garp âlemiyle olan münasebatımız neticesinde, memleketimize ıslahat ve teceddüd [yenilenme] fikirleri girmeye başlayınca mütefekkirin ve rical-i devletin en evvel düşündükleri şey, garp müessesatını [kurumlarını] taklid etmek oldu. Evvelâ kıyafetlerden başlayan garp mukallitliği [taklitçiliği] heyet-i içtimaiyemizin [toplumsal yapımızın] her unsurunda kendini gösterdi ve tıpkı hiç yoktan yeni bir âlem-i içtimaî vücuda getiriliyor gibi yeni vazifeler için yeni uzuvlar, yeni müesseseler meydana çıkarıldı.” (Ağaoğlu:1913a).

Ağaoğlu'na göre Tanzimatçılar Avrupa'dan aktardıkları kanunlar, yaptıkları reformlarla toplumsal sorunları çözmeyi ümit etmiştir. Fakat toplumumuzun ihtiyaçlarını, kendi koşullarını, yapısını görmezden gelmişlerdir. "Biz ne tarihi, ne ananeyi, ne memleketimizin teşkilat-1 hususiyesini ve ne de kavmiyetimizin halet-i ruhiyesini hesaba katmadık.” (Ağaoğlu:1913a). Ona göre Tanzimatçılık sadece yönetim alanında değil toplumsal hayatın her cephesinde olumsuz sonuçlara yol açmıştır.

Mehmet Fuat, "Tasvir-i Efkâr"da yayımlanan yazısında aynı konuyu ele almıştır, Mehmet Fuat'a göre Tanzimatçılar Batılılaşma zorunluluğu hissedince kıyafetten başlayarak Batı taklitçiliğine girişmiştir. Bu konuda yeterince bilgi sahibi olmadıkları içinde işin içinde çıkamamış, sosyal yapıyı da tahrip etmişlerdir. “...İçtimai meseleler hakkında pek az haiz-i vükuf ve salahiyet sahibi olan o adamlar, hakiki bir teceddüdün [yenilenmenin] ne demek olduğunu, bir heyeti-i içtimaiyeye yeniliğin ne suretle idhali [alınması] lazım geleceğini maatteessüf bilemiyordu..." (Fuat:1913) Ona göre bunun sonucunda halkta Batılılaşmanın bir tür taklitçilik, dinsizlik olduğu hissi doğmuş ve Batılılaşma karşıtı bir tepki ortaya çıkmıştır. Ülke elli, altmış sene yerinde saymış, Tanzimat reformları başarılı olamamıştır. Tanzimat fikirleri sadece belirli bir seçkin zümrenin benimsediği bir fikir olarak kalmıştır.

Mehmet Fuat'a göre Tanzimatçılar, eski kurumları sslah etmek yerine yeni kurumlar ikmal etmeye kalkınca, aynı amaca hizmet etmesi gereken kurumlar birbirleriyle mücadele etmeye başlamıştır. "Bir memleketin icabatı [gereksinimleri], ihtiyacı, ananatı nazar-1 itibara alınmayarak yapılan yenilikler, eski mevcutları büsbütün ihlalden başka bir şeye yaramaz.” (Fuat:1913) Ona göre eğer eski kurumlar dönemin şartları göz önüne alınarak yenilenmeye ve çağa uygun hale getirilmeye başlansaydı bu ikilik ve toplumsal tabana dayanmayan yeni kurumların meydana getirdiği bölünme söz konusu olmazdı. 
Yusuf Akçura'ya göre ise Tanzimatçılığın iflasını ilan etmek için henüz erkendir. Tanzimat'ın getirdiği kurumlar, okullar, aydınlar, gazeteler hala Tanzimatçıların elindedir. Akçura, Tanzimatçılığın milli bilincin ortaya çıkmasına çalışmadığı fikrini onaylar. Akçura'ya göre siyasi ve idari Tanzimatçılık bir tür kozmopolitizmdir ve bu fikre inanan Türklerden başka kimse olmamıştır (Akçura:1913).

Özetle Tanzimat reformları hakkındaki kalem kavgalarında ortaya çıkan ağırlıklı görüş Tanzimatçılığın belirli bir program dâhilinde, sosyal kurumların toptan yenilemek yerine bir ikilik yarattığı, kılık kıyafet üzerinden başlayan yenileşme denemelerinin şekilden öze geçemediğidir. Bu yüzden Tanzimatçılık toplumda kök salamamış, bir tür taklitçilik olarak anlaşılmıştır.

\section{Milli Kimlik ve Dini Aidiyet Konusunda Kalem Kavgaları}

Türk Yurdu Dergisinde milli kimlik ile dini aidiyet arasında bir ayrılık olup olmadığı, Türklüğün Müslümanlığa engel teşkil edip etmediği ile ilgili dönemin İslamcı yazarları Süleyman Nazif, Ahmet Naim ile Ahmet Ağaoğlu arasında kalem kavgaları yaşanmıştır. Bu kalem kavgalarında İslamcı kanat dini kimliğin Osmanlı sosyal yapısını birleştirmeye en uygun çözüm olduğunu ve bu yüzden Türkçülüğün toplumsal bünyede bölünmeye yol açacağını savunmuş, Türk milliyetçileri ise bugün artık Türklerin kendi kimliklerini savunmalarının dini aidiyete bir zararı olmayacağını, zaten kendileri dışında her Osmanlı kavminin kendi milli kimliklerine sahip çıktığını belirtmiştir. Onlara göre Türk olmak Müslüman olmaya mani değildir bilakis onu kuvvetlendirecektir.

İlk ele alacağımız kalem kavgası Süleyman Nazif'le Ahmet Ağaoğlu arasında gerçekleşmiştir. Süleyman Nazif, İslamiyet'in her tür millet bağlılığının ötesinde evrensel bir kardeşlik bağı kurduğunu ve bugün Türk milliyetçiliğinin bu bağı zayıflatmaya çalıştığını savunmuştur (Nazif:1913). Bu iddialara Türk Yurdu Dergisinde yanıt veren Ağaoğlu işe temel bir ayrım yaparak başlamıştır. Ona göre kabile bağlılığı anlamına gelen "asabiye" ile millet birbirinden ayırt edilmelidir. İslamiyet, kabile bağlılığına dayanan asabiye'ye karşı savaş açmış ve onu kırmaya çalışmıştır. İslamiyet millet bağına karşı bir mücadele vermemiştir. Ona göre millet olmayı engelleyen, buna karşı çıkan ne bir dini hüküm vardır ve ne bu fiilen gerçekleşmiştir. İslamiyet, Arapların parçalanmış yapısını (asabiye) kaldırarak aralarındaki düşmanlığa son vermiştir. Fakat bunda da başarılı olamamıştır. Peygamber daha hayatta iken kabile bağlılıkları yeniden alevlenmiştir (Ağaoğlu:1913b). 
Bunu takip eden ikinci kalem kavgasında benzer iddialar dile getirilmiştir. Sebilürreşat dergisi yazarlarında Babanzâde Ahmet Naim Türkçülük aleyhinde bir makale yayımlamıştır (Naim:1914, 114). Ahmet Naim de Süleyman Nazif gibi İslamiyet'in her tür millet ve kabile bağlarının ötesinde bir kardeşlik bağı geliştirdiğini, Türk milliyetçiliğinin bu kardeşlik bağlarına zarar verdiğini savunmuştur. Ona göre Türkçülük Avrupa'dan gelen bir düşüncedir ve sosyal bünyemize zarar vermiştir.

Ahmet Naim, Türkçüleri iki kısma ayırmıştır. Birinci kısma "halis Türkçüler" ikinci kısma ise "İslamcı Türkçüler" adını vermiştir. Halis Türkçülerin yeni bir din ve yeni bir millet inşa etmek istediklerini belirten Ahmet Naim, bu grubun "açıkça dinsizlik" peşinde olduklarını söylemiştir (Naim:1914, 115). Halis Türkçülerin gerçeklerin değil hayallerin peşinde olduğunu savunan Ahmet Naim, İslamcı Türkçüler ile aralarında ciddi bir görüş ayrılığı olmadığını belirtmiştir.

Ağaoğlu, Ahmet Naim'in "halis Türkçüler” hakkındaki dinsizlik iddiasına büyük tepki göstermiştir. Türk milliyetçileri içerisinde İslam'a aykırı fikirler taşıyan herhangi bir görüşün olmadığını söylemiştir. Ona göre Türk milliyetçileri için İslam’dan uzaklaşmak düşünülemez. "Din, kavmiyetin en mühim esas ve erkânından olduğu için kavmiyet cereyanını anlayarak, bilerek takip edenler için dinden uzaklaşmak kâbil bile değildir." (Ağaoğlu:1914a, 373).

Ağaoğlu, Süleyman Nazif'le olan kalem kavgasında kullandığı savunma biçimine devam etmiş, kabilecilik (asabiye) ile milliyet arasında bir ayrım yapmıştır. Ona göre İslamiyet'in reddettiği millet bağlılığı değil kabile veya soy bağlılığına dayalı övünmedir. Peygamber, Arap toplumunda birleşmeyi engelleyen kabileciliği yıkmaya çalışmıştır. “İslâmiyet'in en birinci, en büyük maksadı şu Arabîliği def ederek asabiyeti kaldırarak Arap kavminin vahdetini [birliğini] temin eylemek, Araplıkta bir vicdan-1 umûmî, bir gaye-i müştereke [ortak bir amaç] husule getirmekten ibaretti.” (Ağaoğlu:1914a, 375). Ağaoğlu'na göre İslamiyet millet bağlılığını reddetmemiş tam aksine Arap toplumunun birleşme ve bütünleşmesini sağlamıştır:

"Fakat bütün bunlardan istihraç edilecek [çıkarılacak] gayr-i kabil-i inkâr [inkar olunamaz] ve tevîl bir hakikat vardır ki, o da İslâmiyet'in kavmiyet esasını yıkarak değil onu temin ederek itilâ etmiş [yükselmiş] olduğundan ibarettir! İslâmiyet'i saha-i cihana atmadan evvel İslâmiyet'in başında bulunan Araplık vahdet-i milliyesini [milli birliğini], Araplık bünye-i milliyesini [milli bünyesini] 
kurmak icap ettiğini takdir ettiler! Ve İslâmiyet milliyeti ezmekle değil, onu tesis ederek ona istinaden [dayanarak] yürüdü. Ve bu yolda İslâm banilerine [yapıcılarına] karşı çıkmış en birinci, en metin mania [engel] asabiyet idi. Araplar arasındaki aşiret, kabile belâsı idi ki, Arapların uhuvvet-i milliyelerine [milli kardeşliklerine] mâni olmakla beraber Arap vicdan-1 millîsinin şuurî bir surette teşekkülüne bir set teşkil ediyordu.” (Ağaoğlu:1914a, 376).

Ona göre peygamberin vefatı ile birlikte tekrar eski kabile bağlılığı baş göstermiş, ayrılıklar ortaya çıkmıştır. Hz. Osman döneminde bu ayrılıklar savaşa dönüşmüş ve böylece Arap birliği zarar görmüştür. Arapların birliğini kaybetmeleri ise güçlerini alıp götürmüştür:

"Müslüman Araplar vahdet-i milliye [milli birlik] esaslarına sadık kaldıkça aralarında azîm bir aheng, bir intizam, [düzen] bir devam olmakla beraber dehâ-yı millînin [milli dehanın] en yüksek ve en vâsi [geniş] tezahüratına [görünümüne] nail oldular. Fakat şu esas bozulur bozulmaz yine aynı Müslüman Araplar, o dehânın feyiz ve bereketinden mahrum kalmaya başlıyorlar. İslamiyet'in en birinci teşebbüsü, şu vahdet-i milliye esasını temin eyleyerek, onun sayesinde feyizdar olan Arap dehâ-yı millîsi din-i mübînin ilâsında istihdam eylemekten ibaretti." (Ăgaoğlu:1914b, 389).

Ağaoğlu, Araplığın yükselmesini milli birliğe bağladıktan sonra İslamiyet'in milli bağlılıkları dışlamadığını, sadece bunu bir övünme konusu olmaktan çıkardığını söylemiştir. İslamiyet'e giren çeşitli milletler de kendi milliyetlerini korumuşlardır.

"Hiçbir ayet veya hadiste Müslüman olanların kendi dillerini, milliyetlerini bırakmaları gerektiği ile ilgili bir emir yoktur. İslâmiyet, İslamlardan dine sadık ve uhuvvet-i İslâmiyeye [İslam kardeşliği] merbut kalmalarını [bağlı kalmalarını] talep eder fakat kendi kavmiyetlerinden, kendi hususât-1 zâtiyelerinden [özel niteliklerinden] vazgeçmeyi hiç bir zaman talep etmemiştir ve edemezdi. Çünkü böyle bir talep, tabiatın hilafında [karşısında] olduğu için teklif-i mâlâ-yutak [güç yetmez bir teklif] olurdu!” (Ağaoğlu:1914b, 390). 
Ağaoğlu, kendilerinin Türkleri eski Şaman inancına geri götüreceği iddialarını ise saçma bulmuştur. Ona göre İslamiyet Türklerin milli dinidir. Türklük, Müslümanlığı kendisi için bir “şeref” olarak görmektedir.

“İslâmiyet Türk'ün dinidir, din-i millîsidir. Türk, İslamiyet'i cebren [zorla], mahkûm, mağlûp olarak değil, hâkim, galip olarak kabul etmiştir. Bin seneden beridir ki, İslâmiyet'in en ağır yüklerini omzuna alarak taşımaktadır. İslâmiyet yolunda Türk her şeyi unutmuştur. Lisanını, edebiyatını, iktisadiyatını ve hatta bazen mevcudiyet-i kavmiyesini bile! Türk'ü meşiyet-i ezeliye Altay dağlarından kaldırarak İslâmiyet'in en felâketli günlerinde o tarikat-1 ilâhiyenin imdadına sevk eylemiştir ve zannediyoruz ki Türk şu vazifesini beleğa mâbelâğ [layıkıyla] ifâ etmiştir. İslâm ve İslâmiyet karşısında alnı açık, başı yüksektir... Türkçüler, kable'l-İslâm [İslam öncesi] Türk tarihinden, Türk hayatından bahsetmeye koyuldukları zaman mu'terizler [itiraz edenler] "Eski Türk dini olan Şamanizme avdet ediyorlar" diye bağırmaya başlıyorlar. Bu gibi İstinadât, [iddialar] en menfur iftiralardır. Bir Türkçü nasıl Şamanizm'e avdet etmek [dönmek] ister ki -Türk tarihinin en şanlı sayfaları İslâmiyet yolunda isâr ettiği [döktüğü] kanından teşekkül etmiştir.” (Ağaoğlu:1914b, 391).

Özetle milli kimlik ve dini aidiyet konusunda dergide yaşanan temel tartışma İslamiyet'in milli bağl1lığı reddedip, etmediği yönünde olmuştur. Gerek Süleyman Nazif gerekse de Ahmet Naim, Türk milliyetçiliğinin İslam birliğine zarar vereceğini, yeni ayrışmalara yol açacağını ve ayrıca dergide dile getirildiği biçimiyle İslamiyet'in milli bağlığın üstünde evrensel bir kardeşlik bağı geliştirdiğini savunmuşlardır. Ağaoğlu ise verdiği yanıtlarda İslamiyet'in kabile bağlıklarını reddettiğini, milli bağlılığa ilişkin ise bir yasaklayıcı bir tutumunun olmadığı şeklindedir. Ona göre Müslüman olan her toplum Arap olmayacaktır. İslam'ın böyle bir bakış açısı yoktur. Ağaoğlu'nun tutumunda eklektik bir taraf göze çarpmaktadır.

\section{Sonuç}

II. Meşrutiyet sonrasında Türklügün her alanda yükselmesini hedefleyen çeşitli dernek, cemiyet ve vakıflar kurulmuştur. Türk Derneği, Türk Yurdu Cemiyeti, Türk Ocağı gibi. Bunların çıkarmış olduğu Türk Derneği Dergisi, Türk Yurdu Dergisi, Halka Doğru, 
Milli Tetebbular Mecmuası gibi çeşitli gazete ve dergilerde Türk milliyetçiliğinin savunusu yapılmıştır. Rusya Türklerinin öncülük ettiği Türk milliyetçi programına dönemin Osmanlı aydınları içerisinden de ciddi bir destek gelmiştir.

Türk Yurdu Dergisi çeşitli görüşlerden entelektüel çevrenin buluştuğu bir fikir kulübü gibi çalışmıştır. Dergide çok canlı fikir tartışmaları ve kalem kavgaları yaşanmıştır. Bu kalem kavgalarından dördünü incelediğimiz makalemizde temel olarak dönemin fikir tartışmalarını ele alındı.

İlk tartışma dil ve edebiyatla ilgili olmuş dergide kullanılan dilin Osmanlıcayı büsbütün ortadan kaldırarak yeni bir dil yaratma peşinde olup olmadığı sorularına yanıt verilmiştir. Mithat Cemal, Celal Nuri gibi isimlerin dergiye yönelik eleştirileri yanıtlanmıştır. Derginin esas olarak toplumu dil etrafında birleştirmek peşinde olduğu ve bunun için de dilin halkın anlayabileceği bir forma kavuşması gerektiği vurgulanmıştır.

İkinci kalem kavgası eğitimde ideal eksikliği, azınlık okullarının sosyal bünyeye verdiği zarar ve eğitim dilinin Türkçe olması gerektiği hakkında olmuştur. Bu kalem kavgalarında Yusuf Akçura, Halide Edip, Nezihe Muhlis, Mehmet Fuat, Ahmet Ağaoğlu gibi isimler görüş belirtmiştir. Azınlık okullarının idealsiz, ruhsuz, milli terbiyeden yoksun bir gençlik yetişmesine neden olduğu vurgulanmıştır.

Üçüncü kalem kavgası Tanzimat reformlarının başarılı olup olmadığı, başarısızsa bunun nedenleri hakkındadır. Ağırlıklı görüş Tanzimatçılığın iflas ettiği, toplumda bölünmelere neden olduğu, reformların şekilden öteye geçemediği ve en önemlisi de programın milli bir hedefinin olmadığı şeklindedir.

Dördüncü kalem kavgası din ile milliyet bağlılığı arasında bir çatışma olup olmadığı hakkında olmuştur. Türklüğün Müslümanlığa mani olup olmadığı tartışılmış, İslamcı kanattan Ahmet Naim, Süleyman Nazif gibi isimler Müslümanlık varken Türklüğe ihtiyaç olmadığını, Türklüğün diğer Müslüman kavimlerde de başka ayrılıkçı eğilimlere yol açacağı endişesini dile getirmiştir. İslam'ın evrensel kardeşlik bağlılığının ötesinde başka bir bağa ihtiyaç olmadığını savunmuşlardır. Ahmet Ağaoğlu buna verdiği yanıtlarda Müslümanlığın kavmiyetçiliği değil kabileciliği yasakladığını, ayrıca Türklüğün güçlenmesinin İslam’ın da güçlenmesini sağlayacağını ifade ederek yanıt vermiştir. 


\section{KAYNAKÇA}

AĞAOĞLU, A. (1913a, 14 Mart). “Tanzimatçılı̆̆ın İflası”, Jön Türk.

AĞAOĞLU, A. (1913b, 18 Eylül). “Cevaba Cevap”, Türk Yurdu, 4, 48.

AĞAOĞLU, A. (1914a, 23 Temmuz). “İslam’da Davayı Millet”, Türk Yurdu, 70.

AĞAOĞLU, A. (1914b, 6 Ağustos). “İslam’da Davayı Millet II”, Türk Yurdu, 71.

AKÇURA, Y. (1912a, 25 Ocak). "Mithat Cemal Beyefendiye” Türk Yurdu, 1, 5.

AKÇURA, Y. (1912b, 27 Haziran). "Emel ve İdeale”, Türk Yurdu,2, 16.

AKÇURA, Y. (1912c, 25 Temmuz). "Halide Hanımefendi Hazretlerine”, Türk Yurdu, 2, 18.

AKÇURA, Y. (1913, 20 Mart). “Tanzimatçılık Aleyhine”, Türk Yurdu, 2, 35, 193.

AKÇURA, Y. (1915, 21 Ocak). “Düşünülecek Meselelerimizden”, Türk Yurdu, 7, 75, 41.

AKÇURA, Y. (2008). Türkçülüğün Tarihi, 3. Baskı, İstanbul: Kaynak Yayınları.

ANONIM (1916, 9 Mart). “Talim ve Terbiye”, Türk Yurdu, 9, 104.

ANONIM, (1911a). “Türk Derneği Tasdik Edildi”, Türk Derneği, 1327165.

ANONIM, (1911b). “Şubelerimize”, Türk Derneği, 1327 199-200.

CEMAL, M. (1913, 28 Aralık). “Akçuraoğlu Yusuf Beyefendiye”, Türk Yurdu, 1,3, 84.

DEVLET, Nadir (2011). İsmail Gaspıralı, İstanbul: Başlık Yayın Grubu.

EDİP, H. (1912, 17 Temmuz). "Mecburi Cevap, Mecburi Cevap”, Tanin, 3.

ERGIN, Osman (1940). Türkiye Maarif Tarihi, Tanzimat Devri Mektepleri, Cilt 2, İstanbul: Osmanbey Matbaasi.

FUAT, M. (1913, 15 Mart). "Mektep - Medrese”, Tasvir-i Efkâr.

FUAT, M. (1914, 24 Aralık). "Lisan Meselesi”, Turan.

HİKMET, A. (1911). “Dilimiz II”, Türk Derneği, 2, 47.

KÜÇÜK, S. (2012) “Çağatay Türkçesiyle İlgili Makaleler Bibliyografyası Denemesi”, Taksad, Cilt $1-3,25,41$

MUHLIS, N. (1912, 17 Temmuz). “İdeal Makalesi Münasebetiyle,” Hak. 
NADİ, Y. (1913, 12 Mart). “Tanzimatçılığın İflası”, Tasvir-i Efkâr.

NAİM, B. A. (1914, 23 Nisan). “İslam’da Davayı Kavmiyet”, Sebilürreşat, 114.

NAMI, Kazım (1911). “Türkçe mi Osmanlıca mı?” Genç Kalemler, I, 12, 132,133, 136.

NAZİF, S. (1913, 14 Ağustos). "Ahmet Agayef Beyefendiye”, İctihat.

NURİ, Celal (1912, 25 Ocak). “Akçuraoğlu Yusuf Bey'e”, Türk Yurdu, 1, 5, 147-48.

SUPHİ, Hamdullah (1918, 30 Haziran). "Türk Ocağı İdare Raporu”, Türk Yurdu, XIV, $159,215-216$.

TUNAYA, Tarık Zafer (1998). Türkiye'de Siyasal Partiler I, 2. Baskı, İstanbul: Hürriyet Vakfı Yayınları.

T.Y. (1911, 14 Aralık) “Küçük Muhtıra”, Türk Yurdu, 1,2, 56.

ÜSTEL, Füsun (1997). Imparatorluktan Ulus-Devlete Türk Milliyetçiliği: Türk Ocaklart (1912-1931), İstanbul: İletişim Yayınları.

VAMBERY, A. (1913, 13 Kasım). “Müteveffa Vambery'nin Türk Şairi Emin Beyefendiye Bir Mektubu", Türk Yurdu, 3, 52, 70. 